\title{
Redefinition of the Modern, Native Epistemology and Global Identity
}

The Confucian revival and the "China model" in the work of Arif Dirlik

\section{David Bartel}

Translator. Michael Black

\section{(2) OpenEdition}

\section{Journals}

Electronic version

URL: https://journals.openedition.org/chinaperspectives/6125

DOI: 10.4000/chinaperspectives. 6125

ISSN: 1996-4617

\section{Publisher}

Centre d'étude français sur la Chine contemporaine

Printed version

Date of publication: 15 March 2013

Number of pages: 99-102

ISSN: 2070-3449

\section{Electronic reference}

David Bartel, "Redefinition of the Modern, Native Epistemology and Global Identity", China Perspectives [Online], 2013/1 | 2013, Online since 01 March 2013, connection on 17 February 2022. URL: http:// journals.openedition.org/chinaperspectives/6125; DOI: https://doi.org/10.4000/chinaperspectives. 6125 


\title{
Redefinition of the Modern, Native
}

\section{Epistemology and Global Identity}

\author{
The Confucian revival and the "China model" in the work of Arif Dirlik
}

DAVID BARTEL

C hinese studies specialists are familiar with the writings of Arif Dirlik. (1) The recent release of a collection of texts published by the Chinese University of Hong Kong (CUHK) on the occasion of a series of lectures delivered at Tsinghua University in 2010 has the advantage of bringing together in one volume texts that represent different aspects of a work as complex as it is singular. This book provides a wide-ranging look at the reflections of this renowned specialist in Chinese anarchism and Marxist historiography, and offers an overview of his original perception of intellectual and cultural developments that go beyond China. He takes on the phenomenon of capitalist globalisation and analyses the apparently contradictory resurgence of traditions that only yesterday seemed to be condemned by the dominant discourse of Eurocentric modernity. These pages attempt to clarify the essential issues that span the dozen texts in the collection, in particular the indigenisation of knowledge in the context of capitalist globalisation.

Born in 1940, Arif Dirlik is a historian of communism and a radical social critic. Of Turkish origin, he has spent most of his academic career at American universities. Specialising first in the history and historiography of Chinese anarchism and communism, (2) during the 1990s he became a particularly astute observer and a sophisticated theorist of the new linguistic and historical arrangements that have altered China's accession to a complex and still unfinished globalisation process. From the mid 1990s, in parallel with the significant intellectual reconfiguration following the dramatic events of 1989 - both in China and around the world - Dirlik undertook work that combines reflections on deconstructing the presuppositions of Eurocentric modernity (in particular its modernising discourse, ideology of development, and liberal democracy) - which he renames Euromodernity - with the return of reflections on national identity in China. At the same time, he foreshadowed the renewal of Marxist theory as a tool for analysing the contemporary world. (3) This sensitivity to identity - which must be differentiated from the narrow nationalism that, paradoxically, sometimes feeds on it - should indeed be reconsidered in the light of postmodern, postcolonial, and subaltern theories in the context of a globalised "cultural China," as well as in light of the fact that communism can no longer answer - as Mao did for a time - the two fundamental questions of Chinese modernity: identity and its corollary, the link to the "Other," usually identified with the West. ${ }^{(4)}$ It should be noted that Dirlik's origins allow him to share a certain awareness, and even some points of view, with postcolonial intellectuals. ${ }^{(5)}$ However, he remains wary of the exploitation of this new intellectual wealth by a form of nationalism that endorses cultural relativism in order to invalidate any attempt at a critical approach to Chinese globalisation from a historical perspective. Dirlik takes issue with a concerted effort to depoliticise knowledge by moving po-

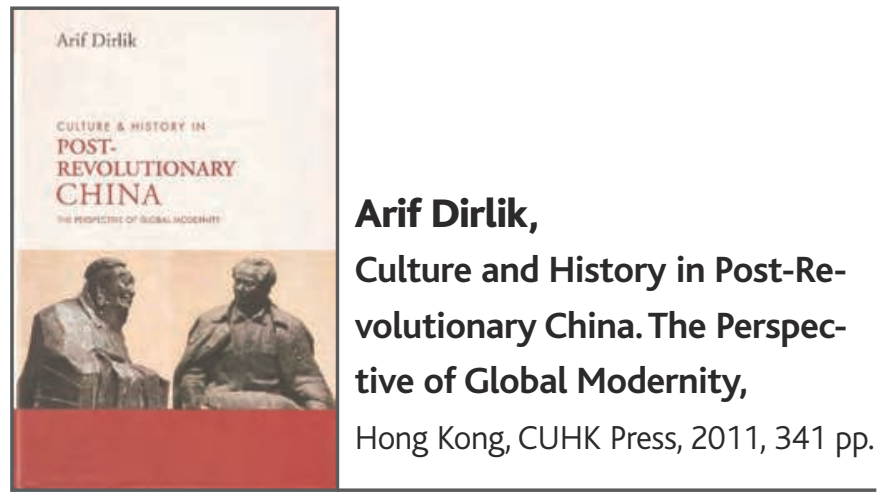

litical issues into the field of culture, and calls for urgent attention to the political meaning to be given to culturalist claims about epistemology (p. 61). In this context, the occasionally difficult reading of his writings offers a scholarly argument in which China, far from essentialist discourses, regains its uniqueness. This argument, by going beyond China's national borders, forces us to rethink Chinese experience in world history in the course of being forged between "identity," "globalisation," and "capitalism."

\section{Native epistemology}

The book focuses on three benchmarks: the repudiation of the revolutionary sequence after 1978, the return of the Chinese past (long considered an embarrassing obstacle) as the very source of power and national wealth, and the context of globalisation (pp. ix-x). From this perspective, the revival of Confucianism in China is part of a broader rise of previously disqualified

1. China Perspectives has recently published two contributions by Arif Dirlik: "Guoxue/National Learning in the Age of Global Modernity," Vol. 1, 2011, and "Mao Zedong in Contemporary Chinese Official Discourse and History," Vol. 2, 2012.

2. His publications include: Revolution and History: Origins of Marxist Historiography in China, 19191937, Berkeley, University of California Press, 1978; The Origins of Chinese Communism, New York, Oxford University Press, 1989; Anarchism in the Chinese Revolution, Berkeley, University of California Press, 1991; and Schools into Fields and Factories: Anarchists, the Guomindang, and the National Labor University in Shanghai, 1927-1932 (with Ming Chan), Durham, Duke University Press, 1991.

3. Arif Dirlik, "Socialism in China: A Critical Overview," in Kam Louie (ed.), The Cambridge Companion to Modern Chinese Culture, New York, Cambridge University Press, 2006, pp. 169-170. On the resurgence of Marxism, cf. Stuart Jeffries, "Why Marxism is on the rise again," The Guardian, 4 July 2012. www.guardian.co.uk/world/2012/jul/04/the-return-of-marxism (consulted on 29 July 2012).

4. Arif Dirlik, The Postcolonial Aura - Third World Criticism in the Age of Global Capitalism, Boulder, Westview Press, 2000.

5. As stated in the introduction to his 1994 article, "The Postcolonial Aura - Third World Criticism in the Age of Global Capitalism," Critical Inquiry, Vol. 20, No. 2, Winter 1994, p. 328. 
traditions and ideologies authorised by the repudiation of Eurocentrism. In China, Confucianism had evolved from a discourse of universal scope to a mere cultural referent limited to a national past. Dirlik sees its renewal as part of a global resurgence of indigenous claims to "ways of seeing" and "ways of knowing" that, from Islam to Hinduism, from Buddhism to Turkish nationalism, take place at the same time, while responding to very different social and historical contexts (p. 37). These appeals to tradition in order to "sinicise" sociology, or to "islamise" anthropology, as well as the return to "classical" epistemologies in order to reaffirm "national studies," wherever they come from, have in common a reference to old inheritances. ${ }^{(6)}$ Yet, far from being the frozen relics of a glorious past, those traditions are in fact products of modernity (pp. 38-39), which the Israeli sociologist Shmuel Eisenstadt has called "multiple modernities." (7)

To Dirlik, globalisation coincides with a disillusionment with universalism, and in turn has opened up spaces for rethinking alternative ways of knowing (p. 52). This "provincialisation" of Europe is not least a result of the universalisation of knowledge and its appropriation by various social and intellectual worlds that no longer recognise the Euro-American monopoly. It marks the transformation of Third World intellectuals, who are appropriating the legacy of modernity (p. 53). Here, Dirlik reaches a paradox. Global or globalised modernity can be seen as the end of colonial hegemonies, as it has helped plunge the former colonised into a form of modernity that is not colonial. But we can also see this as a universalisation and a deepening of colonialism through global internalisation of the premises of a capitalist modernity closely linked to colonialism (p. 55). From this ambiguity arises the possibility that our present (the internationalisation of capital, human migration, cultural conflicts), rather than being a simple decolonisation, is a reconfiguration of colonialism (p. 56). Dirlik has pointed out the importance of American academia in the internationalisation of standards of knowledge and norms of capitalism. He extends this reasoning by arguing that "the reassertion of traditions often takes the form of articulating those traditions to the demands of global capitalism" (p. 57).

Thus, from the Global Village to the Internet, the emergence of globalisation as a paradigm raises many questions centred on a fundamental paradox: the awareness that globalisation is the product of a Eurocentric world order that it calls into question (p. 48). Challenges to the Eurocentric order are thus built on native or nativist pasts, but without calling for a return to those pasts. Nativism has no choice but to work with some form of colonial modernity (p. 48), otherwise it would condemn itself to a relativistic provincialism that refutes universalist claims by denying the longue durée of trade and global interaction (p. 49). The difference is that globalisation today has renounced the Eurocentric teleology of modernisation by accommodating the possibility of specific national trajectories in the deployment of modernity (p. 50). What distinguishes our time from past times is "a willingness to listen to invocations of cultural legacies, not as reactionary responses to modernity, but as the very conditions of modernity" (p. 50). The very process of "cultural extroversion" (8) reveals "the impossibility of sustaining reified, holistic notions of tradition, which have already been transformed by modernity and appear as sites of conflict between different social interests and different visions of the modern" (p. 57). Also revealed in these attempts at appropriating modernity is the pervasive influence of the ideology of development (developmentalism) that has propagated a global faith in a better future. To Dirlik, the situation is clear: it is not by denying Euro-American cultural hegemony that "decolonisation of the mind" can be achieved. It is much more in a radical refutation of this belief in unlimited development that Arif Dirlik foresees the possibility of rebuilding a more egalitarian world order, an assessment that is confirmed every day by "the evidence of the increased marginalisation and inequality worldwide which has accompanied the globalization of capital" (p. 58).

\section{The Confucian example}

In this perspective, Confucianism - and its renewal - is a central axis of Arif Dirlik's reflection on ethno-epistemological claims arising from postrevolutionary capitalist globalisation. In this way, he integrates China into a set of broader questions about the relationship between civilisation and culture, identity and globalisation. "For more than half a century, Chinese and foreign scholars alike condemned Confucianism to the proverbial dustbin of history, as an ideology rendered defunct by Chinese progress toward modernity, be it under Capitalism or Communism" (p. 97). The May Fourth generation of intellectuals made Confucianism responsible for all the social and political problems of the country. Manipulations by unscrupulous politicians further damaged its reputation. Finally, Dirlik sees the failed attempts to articulate Confucianism with Euromodernity as having completed its discrediting as a coherent philosophical system. Thus, for several generations, it has seemed an almost paradigmatic example of an outdated ideology, a sentimental residue of attachment to the memory of a backward-looking Chinese culture unsuited to the modern world. In any case this was the "modernist" reading long endorsed by works that became classics and have marked the Western perception of China, influenced by the radicalism of the early Chinese modernisers, as Dirlik recalls. ${ }^{(9)}$ However, over the last 30 years, Confucius has become global, from Singapore to American universities, most recently with the development of the institutes that bear his name (p. 97). ${ }^{(10)}$ One should, however, pay close attention here: Dirlik does not focus on the philosophical or anthropological aspects of the doctrine, but on the ideological and political dimensions of the Confucian renaissance in the 1980s. ${ }^{(11)}$ He sees this revival as the manifestation of a global postcolonial discourse, originating in East Asia, which was instrumentalised in order to ideologically legitimise the capitalist turn of reforms in China.

Confucianism is now reassessed in the light of recent Asian economic successes, but it cannot ignore the lasting effects of the "identity crisis" that affected Chinese intellectuals confronted with two major Euromodern discourses, liberal and Marxist, during what the Chinese still refer to as the "century of humiliation" (bainian guochi, 1842-1949). Dirlik points out that

6. A brilliant overview of all these phenomena is available in Q. Edward Wang, G. Georg Iggers (eds.), with contributions from Supriya Mukherjee, A Global History of Modern Historiography, Edinburgh, Pearson Education Ltd, 2008. For an excellent introduction to classical Chinese historiography, see Léon Vandermeersch, "La conception chinoise de l'histoire" (The Chinese conception of history), in Anne Cheng (ed.), La pensée en Chine aujourd'hui, Paris, Gallimard, 2007, pp. 47-74.

7. Shmuel N. Eisenstadt, "Multiple Modernities," Daedalus, Vol. 126, No. 1, Winter 2000, pp. 1-29.

8. Jean-François Bayart, "L'historicité de l'Etat importé" (The historicity of the imported state), in J.F. Bayart (ed.), La Greffe de l'Etat - Les trajectoires du politique 2 (Grafting the state - Political Trajectories 2), Paris, Karthala, 1996, p. 30.

9. The best known of these works is probably Joseph Levenson, Confucian China and Its Modern Fate: A Trilogy, Berkeley, University of California Press, 1968. The opposition and hostility he depicts between "modernists" and "traditionalists" has had a long run. Yet the relationship of young reformers to tradition is rather more complex. On the link between intellectuals and traditions, cf. Edward Shils, "Intellectuals, Tradition, and the Traditions of Intellectuals: Some Preliminary Considerations," Daedalus, Vol. 101, No. 2, Spring 1972, pp. 21-34.

10. The first Confucius Institute opened in 2004 in Seoul. There are now more than 300 in more than 50 countries. In addition to teaching the language, the mission of these schools is spreading Chinese "culture."

11. On the philosophical aspects of modern Confucianism, see Sébastien Billioud, "Thinking Through Confucian Modernity," Modern Chinese Philosophy, Vol. 5, Leiden, Brill, 2011. 
modern Chinese thought benefited from "the backing of the two most powerful theories of modernity, Marxism and Weberianism" (pp. 102-103). Marxism sees Confucianism as the ideological expression of a class that ruled over a long period, which was deemed "feudal" and destined to disappear. Conversely, Confucianism can be kept as a marker of Chinese national identity only if it is relegated to a past that is reified and condemned wholesale, "placed in a 'museum,' preserved for posterity and prevented from interfering with the tasks of modernization" (p. 103). ${ }^{(12)}$

Similarly, by designating it as an obstacle to capitalism, Max Weber strongly condemned what he perceived as the shortcomings of Confucianism at the time. Confucian rationalism meant rational adjustment to the world; Puritan rationalism meant rational mastery of the world. ${ }^{(13)}$ As we can see, while one discourse places Confucianism in a museum, the other simply dismisses it. Dirlik sees these condemnations as a little too "convenient" (p. 104). He recalls the comment of the famous reformer Liang Qichao (1873-1929), who believed that while "science" and "democracy" were indeed two worthy legacies of Western modernity, the unprecedented devastation and destruction of the First World War definitively invalidated any blind adherence to the pillars of the Euromodernity. ${ }^{(14)}$ Thus, beginning in the 1930s, in the attempt to reconcile China with the West, there gradually emerged a "new Confucianism" (not to be confused with the "Neo-Confucianism" of the Song Dynasty in the thirteenth century), which sought to reaffirm the intrinsic value of the doctrine, reinterpreting it as an ethical-spiritual system perfectly reconcilable with science and democracy. The names of its advocates are well known, and their political allegiances range from cultural conservatism to (anticommunist) socialism to nationalism, and most often agree with the critiques of modernity formulated by the likes of Candhi in India (p. 104). In 1958, in Hong Kong, Mou Zongsan, Tang Junyi, Zhang Junmai, and Xu Fuguang signed a long "Manifesto to the world for the revaluation of Chinese culture" (Wei Zhongguo wenhua jinggao shijie renshi xuanyan), which was a major milestone in the chronology of Confucian revival, although at the time of its publication circulation of the text was confined to the borderlands of Chinese intellectual life constituted by Taiwan and Hong Kong (p. 106). ${ }^{(15)}$ After the collapse of 1989 and the end of the Cold War (1947-1991), these spaces, in fact, continued to play a central role in the global and post-revolutionary reconfiguration of contemporary "cultural China." (16)

The reversal of fortune in the 1980s came with social, political, and especially economic success. "What was to change almost overnight was not the content of Confucianism, but the evaluation of that content in relation to the question of modernity" (p. 107). In the blink of an eye, what had long been seen as an irremediable obstacle to modernity was transformed into a dynamic force of that modernity, and a model to be imitated. This renaissance coincided more or less with the end of the revolutionary period, symbolised by the death of Mao in 1976, "which was to create a crisis in the historical paradigm based on the teleology of the revolution" (p. 107). Logic would demand that this revival of the tradition should lead to questioning the socialist identity built on the negation of the whole tradition. The very return of Confucianism as the ideology of development invalidates the logic of the twentieth century in China as a whole. There remains only to take the Sinicisation of Marxism as a necessary bridge between communist ideology and the return to a deep cultural structure. The idea of continuity in Chinese history takes on a new meaning: Jin Guantao's "integrated system" or Prasenjit Duara's "cultural nexus of power" may need to be reassessed in the light of this new "regime of historicity," (17) all the more so as in the emulation of economic success other models of "cultural China" have appeared - the Dragons of the periphery - whose success Beijing is eager to recuperate by becoming once again the centre of a modernised Confucian ideological agenda. These economic successes, attributed in large part to Confucianism, also create a new audience: "the managerial public in charge of global corporations" (p. 108) and the managerial ideology where employer paternalism is combined with the dream of workers' docility, a dream that is daily contradicted by social reality.

Overnight, what was considered an obstacle to modernity was transformed into a powerful dynamic driving what has become an exemplary modernity (p. 107). Dirlik lists the "major" moments - conferences, publications - of this Confucian revival, in which Hong Kong (CUHK New Asia College was founded by Qian Mu in 1963) played a particular part as a meeting place between Confucians from various Chinese-speaking entities (p. 110). He also recalls the role of Singapore and Lee Kuan Yew in the political instrumentalisation of "Asian values." He does not forget the importance, everywhere, of official or semi-official support, and the responsibility of American academics in the imposition of a new discourse on Confucianism (p. 113). In this process, Dirlik pays special attention to the American philosopher Tu Weiming, and offers a particularly detailed critical reading of a personality with a complex relation to Chinese culture, who considers himself somewhat paradoxically an heir to the tradition of May Fourth, and argues for a "critical reception of Confucianism in order to reconsider its original moral intent, as against its historical distortion" (p. 133). (18) Dirlik also shows the precise boundaries of the relevance of his discourse. While Tu Weiming is constantly on guard against the "dark side" of historical Confucianism, easily prone to becoming an instrument of autocracy (p. 132), this does not prevent this "fundamentalist missionary in his advocacy of Confucianism" (p. 130) from simultaneously providing his approval to regimes that show little concern for democracy. In any case, these examples of collaboration between certain states and an intellectual discourse achieve their objective: "to assert an Asian/Chinese presence in contemporary capitalism, and Dirlik adds, to participate in the formulation of a coherent ideology for an emerging globalized capitalism" (p. 115).

In all these discussions, in fact, the term "modernisation" is conflated with "capitalism," and the identification of modernity with capitalism - a pos-

12. Levenson, op. cit., Vol. 3, pp. 76-82.

13. Max Weber, The Religion of China, New York, Macmillan, 1951, p. xxix.

14. Tang Xiaobing, Global Space and Nationalist Discourse of Modernity: The Historical Thinking of Liang Qichao, Stanford, Stanford University Press, 1996.

15. The Manifesto is widely available in Chinese on the web: www.readfree.net/htm/ 200605/174478.html (consulted on 7 August 2012). There is also an abridged English translation: Carson Chang, The Development of Neo-Confucian Thought, Vol. 2, New York, Bookman Associates, 1962, pp. 455-83.

16. Tu Weiming, "Cultural China: The Periphery as the Center," Daedalus, Vol. 120, No. 2, Spring 1991, pp. 1-32.

17. Intellectual debates centre around a change in "regime of historicity" marked by three concurrent and permeable processes. Through (1) a renewed critical view of the near and distant past, there is now an official (2) return of a long pre-communist national tradition, which was long derided in the People's Republic of China (PRC). In this reflective view of the past is being constructed a radical social critique of the effects of economic liberalisation, which consequently allows (3) a fresh look at the Western "Other." This new look is inevitably accompanied by a necessary challenge to the very notion of "modernity." Cf. Joël Thoraval and Sébastien Billioud, "Introduction: La Chine des années 2000 - Regards nouveaux sur le politique" (Introduction: China in the 2000s New outlooks on politics), Extrême Orient/Extrême Occident : Regard sur le politique en Chine (Far East/Far West: Outlook on politics in China), Presses universitaires de Vincennes, No. 31, October 2009, p. 25. Text available on the Internet: http://cecmc.hypotheses.org/files/2009/12/Exo31-Introduction-Billioud-Thoraval2.pdf (consulted on 18 March 2012).

18. The idea that the iconoclastic protesters of 4 May 1919 were more mobilised against "moral posturing" (in particular against the treatment of women), specifically in the name of a certain conception of Confucian moral humanism, is a central idea of Vera Schwarcz's famous study on university students in Beijing in the early twentieth century: The Chinese Enlightenment: Intellectuals and the Legacy of the May Fourth Movement of 1919, Berkeley, UCLA Press, 1986. 
tulate of modernising discourses - directs the debates around two issues: the role of Confucianism in the development of capitalism and its possible function in limiting the malfunctions of capitalism. However, after some examples of this Confucian "fever" (education, work, group, harmony...), Dirlik cannot help but notice the internal contradictions among the "proliferating qualifications [...] of the so-called 'post-Confucian hypothesis" (p. 121) and, in addition to the existence of national avatars - Japanese, Korean, Taiwanese, Singaporean - the development of instrumental Confucianisms, whether "vulgar," "folk," "social," or "bourgeois" (p. 125). These principles of classification, which guide the reorganisation of Confucianism as a cultural system, eloquently articulate the distance that has been established between Confucianism as an ideology of modernisation and the cultural tradition that inspired it, and which it seeks to preserve (p. 126). One can feel in these pages the emergence of the idea that this alleged revival is not an adaptation of global capitalism to cultural specificities, but conversely, the adjustment of a system of "values" to the recommendations of a globalised capitalism, whose underlying developmentalist discourse provides the agenda. Dirlik's conclusion, radical as it is, deserves to be quoted in its entirety: "Whether as business ideology, academic discipline, or a source of national identity, its fate [Confucianism] depends on its marketability in a global cultural commodity market. It is a fate it shares with other resurgent traditionalisms of Global Modernity" (p. 155).

\section{The modern and the colonial}

The keys underlying Dirlik's reflection on the contemporary world are probably to be found in the last chapter. As he sees it, while relationships between the First World and the poor or emerging countries are denser than ever, and while their differences are now formulated in a common discursive field, the postcolonial perception of the world remains necessarily marked by relations between colonisers and colonised (p. 276). He returns to the responsibility of the "national bourgeoisies" in the perpetuation of colonial practices and the consequent shift of liberation movements towards socialist alternatives (p. 277). Fighting against capitalism was fighting against colonialism, and vice versa. The Chinese case at the end of the Mao era is understood as a degradation of anti-colonialism into nationalist fundamentalism. Onto Chinese political and economic autarky was grafted an obsession with the national (p. 277), which the discourse of Marxist internationalism had been able to conceal.

Dirlik notes, however, that alternative modernities - born of hybridity or postcolonial fundamentalism - are all contained within the horizon of capitalism. Their success is measured only in terms of global capitalism without the most destructive aspect of modernity ever being questioned: the fetishisation of development. These native traditions, revived as a source of alternative modernities, but never questioning the goals and tools of development, ironically find themselves "rendered into symbolic representations of difference, and evacuated of any substantial content" (p. 279). Thus, the world of global modernity carries within it the features of a colonial modernity of which it is the product. Even though the colonial state has largely disappeared, except in cases of ethnic groups resident in nationstates (such as the Kurds in Turkey, or the Uyghurs in China), "the present world, in its political mapping, its uneven development, its universalization of the nation-state, and even in its shared idea of development, remains very much a product of the modernity Euro/America imposed upon the world" (p. 284). Claims to alternative modernities are only too rarely claims to alternatives to modernity (p. 287), and make the pursuit of material development look like the last universal value, while under the claims to cultural recognition there does not seem to be any affirmation of equality between societies, or of equality within societies (p. 297).

In this thirst for recognition, some players are more eager than others, and China is leading the race. However, Dirlik questions the validity of the Chinese claim to put themselves forward as a "model" (p. 298). Without disputing its undeniable successes, beginning with the escape from material and cultural poverty of hundreds of millions of men and women, he simply wonders if the obsession to imitate and overtake the US model is not primarily a validation thereof. There is not, in fact, any Chinese miracle or "model," but simply the clever - even brutal - exploitation of existing paradigms and an almost naive fetishisation of technology. This is a radical analysis that does not elude the major part played by coercion in a country beset by divisions and social conflict, and confronted with enormous environmental problems (p. 302). A direct consequence of this culturalist deception about "Chinese characteristics" is the burial of the recent past under the weight of an older culture, which in the official discourse remains impervious to social and political developments. This cultural reference is highly useful to justify the restriction of modernisation to science and technology, and to repudiate other political and social aspects of modernisation, which are the very essence of any attempt to modernise, but remain at odds with the "native culture" (p. 300) whose stability has become a dogma.

Finally, we should underscore that the interest of this work, and more widely of the various works of Arif Dirlik, lies in the in-betweenness that is his specificity. A global academic in subaltern studies, a postcolonial intellectual in the American university, he offers a perspective that is all too rare in Chinese studies: the refusal to adopt cultural relativism in the name of liberation from colonialism. The radicalism of Arif Dirlik's discourse is doubly effective. On the one hand, it brings back to life the achievements of Chinese studies (which have sometimes nodded off, mired in easy certainties) with rare vigour and radicalism, particularly by integrating postcolonial semantics into the sinological corpus. On the other, it constantly reminds both the Chinese and others that the multiple possibilities of new modernities brought by postmodern discourses and theories are problematic precisely because of the shift they induce. This relativism all too often leads to tolerance without limits, including "tolerance for oppression." (19) Dirlik thus redefines in consistent terms the mission of the global intelligentsia. The postcolonial intellectual must recognise that in order for the subordinate claim to recognition to reach maturity, postcoloniality, understood as the condition of the intelligentsia under global capitalism, must escape from a systematic critique of the West and apply itself henceforth to providing and developing "practices of resistance against the system of which it is a product." (20) In so theorising the means and ends of the contemporary intellectual, Arif Dirlik redefines the role of the intellectual in globalisation. This, also, is the reason why we should read Arif Dirlik.

\section{Translated by Michael Black.}

I David Bartel is a PhD candidate at the EHESS-CECMC, Paris, and associate doctoral fellow at CEFC, Hong Kong.

EHESS-CECMC, 190-198 avenue de France, 75013 Paris (db.chine@gmail.com).

19. Arif Dirlik, "Postmodernism and Chinese History," boundary 2, Vol. 28, No. 3, Autumn 2001, p. 22.

20. Arif Dirlik, "The Postcolonial Aura," 1994, p. 356. Quoted in: Neil Lazarus, "Introducing Postcolonial Studies," in Lazarus (ed.), The Cambridge Companion to Postcolonial Literary Studies, Cambridge, Cambridge University Press, 2004, p. 6. 